https://doi.org/10.35219/teologie.2020.01

\title{
O ȘANSĂ DE ÎNSĂNĂTOȘIRE SPIRITUALĂ, PENTRU O MAI UȘOARĂ PURTARE A CRUCII PANDEMIEI
}

0 mărturie vie, dinamică, densă și echilibrată vede lumina tiparului, prin cunoscuta fasciculă universitară de teologie și educație, cu deschidere spre slujirea socială și frumusețea iconică a spiritualităţii din arta creștină. Este rodul continuității în mai atenta și mai pronunțata analiză lăuntrică a fiecăruia dintre cei ce am fost chemați să oferim și câte o mărturie pe cât cu putință vie, care să răspundă la așteptările imense și multiplicate ale semenilor noștri cărora, să înțelegem, le aparținem plenar, fără să ne preocupăm dacă vor răspunde pozitiv la demersurile noastre sincere, slujitoare, pline de căldura, de lumina de bunătatea și de iubirea lui Dumnezeu pentru lumea care are libertatea de a-L urma, iubi ori respinge. Important este adevărul că Domnul nu are pe nimeni de pierdut și chiar în ultimul minut al efemerei noastre petreceri în lumea văzută ne deschide larg brațele mereu părintești, disponibile și calde în liniștitoarea viață veșnică.

Pandemia nu înseamnă doar o luptă cu un dușman crâncen, nevăzut și distructiv doar pentru om, ci și o atentă reevaluare a omului, „icoană“ vie a Dumnezeului celui veșnic și „biserică“ vie a comuniunii de dincolo de singurătate, tristețe, teamă ori moarte. „Nu știți că sunteți biserici și că Duhul lui Dumnezeu locuiește în voi?" (I Corinteni 3, 16). De ce? Pentru că „în Hristos locuiește, trupește, toată plinătatea Dumnezeirii și sunteți deplini întru El“ (Coloseni 2, 8-10). Mai mult, Dumnezeu nu Se sfiește să trăiască în „cortul“ neputințelor noastre. Iar pentru primitorul de Dumnezeu, mai întâi la măsurile smereniei și neputinței omenești se deschide imensa perspectivă a comunicării, a conviețuirii tainice și a ajutorului discret dar temeinic și astfel în vâltoarea vieții păcătoase se naște prin har și prin eforturile de despătimire, lu- 
minoasa convertire la realitate. Realitatea lăuntrică cu Dumnezeu în noi înseamnă restaurarea noastră la starea de nevinovăție a copilului preferat de Mântuitorul ca model al celor ce redevin în fapt prețuiții fii ai lui Dumnezeu, curați cu inima și gata să-și deschidă mâinile pentru a-l regăsi pe aproapele și fratele real, fiecare om pe care l-am uitat, l-am ignorat, l-am depărtat sau l-am supărat. Și-n el, mai ales în el - tot omul - este viu duhul lui Dumnezeu.

Tinerii noștri slujitori slujitori ai catedrelor universitare teologice de la Dunărea de Jos și din alte prestigioase Universități au înțeles aceste chemări misionare, spre semeni, cu mandat dumnezeiesc, în timp de grea încercare. Au mai înțeles că orice încercare, din orice motiv ar apărea este și o cruce, uneori mai grea decât ni s-a părut în cazul Pandemiei, dar este și o șansă de însănătoșire spirituală a celor ce înțelegem, dorim și reușim să urmăm acest demers lăuntric, apoi să-l prelungim comunitar, tocmai pentru a ieși dintr-o direcție greșită, perspectivă a psihozei bolii, ca și când ea ar fi mai tare decât puterea și voința luptei pentru sănătate. Conjugarea eforturilor oamenilor lui Dumnezeu din prima linie a luptei, medicii și preoții, ar însemna o mai bună cunoaștere reciprocă, o mai atentă abordare a situațiilor concrete la oameni încercați de boală și o unire reală a metodelor și a mijloacelor de vindecare. Nimeni nu se autoînsănătoșește! Nimeni nu-i preot pentru el, ori medic pentru sine. Pentru celălalt, da! Așa s-ar cuveni să gândim și așa trebuie să făptuim.

Ni se propune în prezentul manual de bune metodologii și bune practici din terenul de cercetare științifică interdisciplinară, din dogoarea convingerilor spirituale ale rugătorilor și din iscusința duhovnicilor urmați de valoroșii noștri medici de pretutindeni, dar susținuți puternic de poporul credincios lui Dumnezeu și Bisericii Sale, „spitalul sufletesc" deschis tuturor, care aplică înțelept sfaturile și ajută cu dragoste jertfelnică pe toți cei afectați de boală, sărăcie și neputință.

Să ajute Hristos Domnul pe toți autorii studiilor profunde menite să ne ofere încredere mai multă în sănătate ca dar al lui Dumnezeu și-n viață ca șansă de a dobândi mântuirea. Recomandăm călduros această „agendă“ de minte, suflet și inimă cu scopul și mai bunei informări, dar 
și al mai înțeleptei îngrijiri de propria sănătate, darul cel mai prețios ce-l putem oferi semenilor noștri, oameni sănătoși în pandemie, „icoane" vii ale iubirii mai tare decât moartea pentru sănătatea sufletească și umană, pentru toată lumea.

† Casian,

Arhiepiscopul Dunării de Jos 